\title{
Pengaruh Konsentrasi Aktivator Kalium Hidroksida (KOH) pada Karbon Aktif dan Waktu Kontak Terhadap Daya Adsorpsi Logam Pb dalam Sampel Air Kawasan Mangrove Wonorejo, Surabaya
}

Nurfitria, N. ${ }^{1}$; Febriyantiningrum, K. $^{2}$; Utomo, W.P. ${ }^{3}$; Nugraheni, Z.V. ${ }^{4}$; Pangastuti, D.D. ${ }^{5}$; Maulida H. $^{6}$; Ariyanti F.N. ${ }^{7}$

${ }^{1}$ Prodi Matematika, Universitas PGRI Ronggolawe, Tuban

${ }^{2}$ Prodi Biologi, Universitas PGRI Ronggolawe, Tuban

${ }^{2,3}$ Departemen Kimia, Insitut Teknologi Sepuluh Nopember, ITS. Kampus ITS Sukolilo, Surabaya

*Corresponding author: nia.nurfitria@unirow.ac.id

\begin{abstract}
This study aims to determine the effect of $\mathrm{KOH}$ activator and contact time of activated carbon from coconut shell on $\mathrm{Pb}^{2+}$ metal ions adsorption in water samples from the Surabaya mangrove Wonorejo region. The initial content of $\mathrm{Pb}^{2+}$ metal ions in the water sample was 1,1890 ppm. Activated carbon was made from coconut shell. Activation was done using $\mathrm{KOH}$ with variations in concentrations of 1,3 , and $5 \mathrm{M}$. The contact time of $\mathrm{Pb}^{2+}$ metal ions adsorption in water samples using activated carbon was varied for 1, 1.5, 2 and 2.5 hours for each variation of $\mathrm{KOH}$ activator concentration. The highest adsorption results were obtained from activated carbon that was activated by $\mathrm{KOH} 1 \mathrm{M}$ with a contact time of 1.5 hours. The number of adsorbed $\mathrm{Pb}^{2+}$ metal ions was 1.5645 ppm or $86 \%$ of the initial concentration.
\end{abstract}

Keywords: activated carbon, adsorption, $\mathrm{Pb}^{2+}$ metal ions.

\begin{abstract}
Abstrak
Penelitian ini bertujuan untuk mengetahui pengaruh aktivator $\mathrm{KOH}$ dan waktu kontak karbon aktif dari tempurung kelapa terhadap adsorpsi logam $\mathrm{Pb}$ di sampel air kawasan mangrove Wonorejo Surabaya. Kandungan awal ion logam $\mathrm{Pb}^{2+}$ pada sampel air berjumlah 1,1890 ppm. Karbon aktif dibuat dari tempurung kelapa. Aktivasi dilakukan menggunakan $\mathrm{KOH}$ dengan variasi konsentrasi 1, 3, dan $5 \mathrm{M}$. Waktu kontak adsorpsi ion logam $\mathrm{Pb}^{2+}$ pada sampel air menggunakan karbon aktif divariasikan selama 1; 1,5; 2 dan 2,5 jam untuk setiap variasi konsentrasi aktivator $\mathrm{KOH}$. Hasil adsorpsi terbanyak didapatkan dari karbon aktif yang diaktivasi $\mathrm{KOH} 1 \mathrm{M}$ dengan waktu kontak selama 1,5 jam. Jumlah ion logam $\mathrm{Pb}^{2+}$ yang teradsorp yaitu sebesar 1,5645 ppm atau 86\% dari konsentrasi awal.
\end{abstract}

Kata kunci: karbon aktif, adsorpsi, ion logam $\mathrm{Pb}^{2+}$. 


\section{Pendahuluan}

Sebagai negara maritim, Indonesia memiliki banyak daerah yang memiliki garis pantai. Garis pantai akan memberikan dampak positif bagi laju pertumbuhan ekonomi suatu daerah jika potensinya dioptimalkan dengan baik. Sebanyak $70 \%$ kawasan pantai dimanfaatkan sebagai hunian, dan sisanya adalah kegiatan manusia untuk menunjang perekonomian seperti budidadya perikanan, perdagangan, perta-nian, pelabuhan, dan pariwisata [1]. Kota Surabaya merupakan salah satu daerah yang dapat memanfaatkan potensi pantai di daerahnya. Kawasan ekowisata hutan mangrove Wonorejo Surabaya adalah wisata edukasi yang cukup populer sehingga memiliki jumlah wisatawan yang stabil setiap harinya. Namun, peningkatan aktivitas manusia melalui penggunaan kawasan mangrove sebagai kawasan wisata akan berdampak pada meningkatnya resiko pencemaran.

Salah satu bahan pencemar yang dapat mencemari kawasan perairan akibat aktivitas manusia adalah logam berat. Kelarutanya yang rendah membuat pencemaran logam berat akan mudah terakumulasi di lingkungan perairan[2]. Salah satu logam berat yang terkandung di perairan kawasan mangrove Wonorejo Surabaya adalah logam timbal $(\mathrm{Pb})$ yang terlarut dalam air membentuk ion logam $\mathrm{Pb}^{2+}$. Pengujian menggunakan alat
Atomic Absorption Spectroscopy (AAS) di Laboratorium Fundamental Jurusan Kimia Institut Teknologi Sepuluh Nopember (ITS), menunjukkan data bahwa terkandung ion logam $\mathrm{Pb}^{2+}$ sebesar 1,1890 ppm dalam sampel air dari kawasan tersebut. Jumlah ini melebihi standar baku mutu sampel air kawasan perairan air yang diperbolehkan, yakni kandungan ion logam $\mathrm{Pb}^{2+} \leq 0,12 \mathrm{ppm}$. Daya toksisitas tinggi yang dimiliki oleh $\mathrm{Pb}$ bersifat racun bagi beberapa spesies perairan [3]. Di kawasan perairan, pencemaran $\mathrm{Pb}$ dapat ditemukan dalam bentuk terlarut dalam air atau tersuspensi dalam sedimen. Kelarutan $\mathrm{Pb}$ dalam air cukup rendah, sehingga kadar atau jumlah pencemarannya dalam air relatif kecil [4]. Walaupun kelarutannya kecil, konsentrasi ion logam $\mathrm{Pb}^{2+}$ dalam air yang melebihi baku mutu air juga akan menyebabkan dampak negatif bagi kesehatan manusia, seperti penurunan hemoglobin, linglung, tekanan darah naik, dan sebagainya.

Oleh karena itu, perlu dilakukan pengolahan air di kawasan mangrove Wonorejo Surabaya untuk mengurangi pencemaran ion logam $\mathrm{Pb}^{2+}$ dalam air. Pengolahan dilakukan secara kimia melalui proses adsorpsi menggunakan karbon aktif berbahan dasar tempurung kelapa. Bahan ini dipilih karena daya adsorpsinya yang baik terhadap ion logam $\mathrm{Pb}^{2+}$ dalam air. Daya 
serap karbon aktif ini dapat diperbesar dengan penambahan aktivator. Kalium Hidroksida (KOH) adalah salah satu aktivator kimia yang mampu meningkatkan adsorpsi ion logam $\mathrm{Pb}^{2+}$ oleh karbon aktif. Namun, konsentrasi KOH yang paling efektif terhadap daya adsorpsi karbon aktif pada ion logam $\mathrm{Pb}^{2+}$ belum didapatkan. Oleh karena itu, dalam penelitian ini dilakukan variasi konsentrasi aktivator $\mathrm{KOH}$ yang berbedabeda. Selain itu, variasi waktu kontak untuk setiap variasi konsentrasi $\mathrm{KOH}$ juga dilakukan untuk mendapatkan waktu kontak yang paling efektif dalam proses adsorpsi ion $\operatorname{logam} \mathrm{Pb}^{2+}$.

\section{Metodologi}

\section{Alat dan Bahan}

Alat-alat yang digunakan dalam penelitian ini adalah stirer dan sentrifuge, ayakan mesh 120, kertas indikator $\mathrm{pH}$, crucible, oven, kertas saring biasa dan Whatman, beberapa peralatan gelas, peralatan Spektrofotometer UV-Vis serta seperangkat AAS. Bahan-bahan yang digunakan adalah tempurung kelapa, sampel air dari kawasan Mangrove Wonorejo Surabaya, aquades, Kalium Hidroksida $(\mathrm{KOH})$, dan Methylene Blue (MB).

\section{Karbonisasi}

Proses karbonisasi pada penelitian ini diadaptasi dari metode yang digunakan oleh Purwanto [5]. Tahap pertama yaitu pengeringan tempurung kelapa secara alami hingga memiliki kadar air maksimum 15\%. Pengarangan kemudian dilakukan dengan membakar tempurung kelapa selama \pm 3 jam. Karbon 120 mesh dari tempurung kelapa didapatkan dengan pengayakan menggunakan ayakan mesh tempurung kelapa yang telah dibakar dan dihancurkan menggunakan palu. Sampel yang tidak lolos ayakan dihancurkan kembali hingga berukuran 120 mesh.

\section{Aktivasi Kimia dan Fisika}

Pada proses aktivasi kimia digunakan perbandingan 1:1:4 untuk campuran antara air, karbon dan $\mathrm{KOH}$ dengan variasi $\mathrm{KOH}$ yaitu 0,1 , 3, dan 5 M. Seluruh variasi campuran dipanaskan dan diaduk menggunakan magnetic stirrer hotplate dengan putaran $200 \mathrm{rpm}$ dan suhu $80^{\circ} \mathrm{C}$ selama 4 jam. Campuran kemudian didiamkan selama satu hari hingga terbentuk endapan. Proses filtrasi dilakukan hingga didapatkan endapan karbon dan filtratnya dibuang. Karbon lalu dicuci dengan menambahkan aquades dan berulang sampai pH nya mendekati netral. Aktivasi fisika karbon aktif dilakukan setelah proses aktivasi kimia dengan cara pengeringan karbon menggunakan crucible pada suhu $110^{\circ} \mathrm{C}$ di dalam oven dengan waktu tahan selama 4 jam untuk seluruh variasi konsentrasi $\mathrm{KOH}$. Karbon aktif yang telah dihasilkan kemudian diberikan kode KA0, KA1, KA3, dan KA5 
untuk setiap variasi konsentrasi $\mathrm{KOH}$ yaitu 0 , 1, 3, dan $5 \mathrm{M}$.

\section{Pengukuran Luas Permukaan Karbon}

\section{Aktif}

Luas permukaan karbon aktif dapat ditentukan dengan mengukur daya adsorpsi karbon aktif terhadap Methylene Blue. Prosedur yang digunakan untuk penentuan luas permukaan karbon ini mengacu pada penelitian yang dilakukan oleh Suhendarwati dkk. [6]. Tahap pertama yang dilakukan adalah pembuatan kurva kalibrasi larutan Methylene Blue dengan mengukur absorbansi larutannya dengan $0,1,2,3$, dan 4 ppm mengunakan spektrofotometer UV-Vis pada panjang gelombang $664 \mathrm{~nm}$. Kurva standar Methylene Blue didapatkan dengan membuat kurva dengan konsentrasi (ppm) sebagai sumbu $\mathrm{x}$ dan sumbu $\mathrm{y}$ adalah absorbansi dengan regresi linier persamaan garisnya menggunakan rumus $\mathrm{y}=\mathrm{ax}+\mathrm{b}$. Persamaan ini yang akan digunakan untuk menentukan Methylene Blue yang dapay diadsorp oleh karbon aktif sehingga dapat diketahui luas permukaannya.

Tahap kedua setelah didapatkan kurva kalibrasi yaitu pengukuran jumlah adsorpsi karbon aktif terhadap Methylene Blue dengan menambahkan 2,5 gram karbon aktif KA0, KA1, KA3, dan KA5 ke dalam 20 mL larutan Methylene Blue 100 ppm di lima labu Erlenmeyer dan diaduk menggunakan shaker selama 1 jam. Filtrat dari hasil penyaringan perlakuan ini dianalisis menggunakan spektrofotometer UV-Vis pada panjang gelombang $664 \mathrm{~nm}$. Absorbansi yang didapatkan disubtitusi ke dalam persamaan regresi linier kurva kalibrasi untuk mengetahui konsentrasi Methylene Blue dalam filtrat. jumlah Methylene Blue yang teradsorp oleh karbon aktif didapatkan setelah mengurangkannya dengan konsentrasi awal sebelum adsorpsi dilakukan [7]. Jumlah Methylene Blue yang teradsorpsi oleh karbon aktif dapat digunakan untuk menghitung luas permukaan karbon aktif hasil aktivasi kimia dan fisika yaitu dengan rumus pada Persamaan 2.1

$$
S=\frac{X m \cdot N \cdot a}{M}
$$

$$
\begin{gathered}
\text { Dimana } S=\text { Luas permukaan adsorban }\left(\mathrm{m}^{2} / \mathrm{mg}\right) \\
\mathrm{Xm}=\text { Banyaknya MB yang teradsorp } \\
\mathrm{N}=\text { Bilangan Avogadro }\left(6,02 \times 10^{23}\right) \\
\mathrm{A}=\text { ukuran } 1 \text { molekul adsorben } \mathrm{MB}\left(197 \times 10^{-20}\right) \\
\mathrm{M}=\text { Berat Molekul MB }(320,5 \mathrm{~g} / \mathrm{mol})
\end{gathered}
$$

\section{Metode Adsorpsi Logam Pb oleh Karbon}

\section{Aktif}

Proses adsorpsi $\mathrm{Pb}$ dari sampel air kawasan Wonorejo dilakukan dengan proses batch. Proses ini dimulai dengan mencampur 2,5 g karbon aktif KA0, KA1, KA3, dan KA5 dan kemudian masing-masing ditambahkan $100 \mathrm{~mL}$ sampel air yang sudah diukur konsentrasi $\mathrm{Pb}$-nya menggunakan alat AAS (Atomic Absorption Spectrophotometer) dan disebut dengan $\mathrm{Pb}$ awal. Pengadukan kemudian dilakukan menggunakan magnetic stirrer dengan kecepatan 700 rpm pada 
variasi waktu kontak selama $1 ; 1,5 ; 2$; dan 2,5 jam. Filtrat dari campuran didapatkan setelah proses penyaringan menggunakan kertas saring (Whatman 42) yang kemudian dikarakterisasi kembali menggunakan alat AAS untuk mengetahui konsentrasi $\mathrm{Pb}$ akhir. Penurunan kadar $\mathrm{Pb}$ dalam sampel air oleh proses adsorpsi menggunakan karbon aktif dari tempurung kelapa dengan aktivator $\mathrm{KOH}$ dapat ditentukan dengan mengurangi konsentrasi $\mathrm{Pb}$ awal dengan $\mathrm{Pb}$ akhir hasil karakrerisasi.

\section{Hasil dan Pembahasan}

\section{Karbonisasi Tempurung Kelapa}

Proses karbonisasi dilakukan untuk mendapatkan karbon dari tempurung kelapa. Proses ini dilakukan dengan pengarangan yang bertujuan untuk menghilangkan komponen-komponen lain yang terkandung di dalam tempurung kelapa. Pada proses ini dilakukan di ruangan terbuka sehingga hasil yang didapatkan tidak murni arang atau karbon saja, tetapi tercampur dengan abu karena tempurung kelapa teroksidasi disebabkan lingkungan yang tidak kedap udara. Namun, hal ini tidak memiliki pengaruh yang signifikan terhadap proses adsorpsi karena karbon hasil pengarangan masih akan diaktivasi.

\section{Aktivasi Kimia dan Fisika}

Proses aktivasi karbon menjadi karbon aktif dapat dilakukan melalui secara kimia atau fisika. Salah satu tujuan proses ini adalah untuk meningkatkan luas permukaan karbon. Pada aktivasi secara kimia, perbedaan bahan aktivasi yang digunakan memiliki pengaruh yang berbeda-beda terhadap luas permukaan karbon aktif. $\mathrm{KOH}$ adalah aktivator kimia yang baik pada karbon karena dapat meningkatkan luas permukaannya hingga $3000 \mathrm{~m}^{2} / \mathrm{g}$. Selain itu, $\mathrm{KOH}$ yang juga bertindak sebagai basa kuat yang dapat menghilangkan zat pengotor dalam karbon hasil pengarangan yang kurang sempurna seperti zat volatil dan tar.

Produk karbon aktif hasil aktivasi kimia pada penelitian ini ditemukan sedikit serbuk putih seperti abu. Hal ini dikarenakan sifat basa kuat larutan $\mathrm{KOH}$ yang korosif sehingga menghasilkan senyawa karbonat/ kapur hasil reaksi dengan karbon.

Reaksi karbon dengan $\mathrm{KOH}$ juga akan mengeluarkan air (dehidrasi) karena $\mathrm{KOH}$ merupakan dehydrating agent. Reaksi dehidrasi ini akan membuat karbon terkikis dan terjadi peningkatan luas permukaan karbon aktif karena pembentukan pori-pori yang lebih banyak sehingga diharapkan efisiensi adsorpsinya terhadap ion logam $\mathrm{Pb}^{2+}$ akan meningkat. Pori-pori tersebut yang akan memberikan peranan penting dalam penyerapan ion logam $\mathrm{Pb}^{2+}$ pada sampel air dari kawasan Mangrove Wonorejo Surabaya.

Karbon aktif basah hasil aktivasi kimia kemudian melalui proses aktivasi fisika yang 
menghasilkan karbon aktif yang kering, mengalami pengurangan massa dan berwarna hitam pekat. Pengurangan massa pada karbon aktif ini disebabkan ukuran partikelnya mengecil karena kehilangan kandungan air, sedangkan zat volatil dan tar sudah hilang pada aktivasi kimia.

\section{Pengukuran Luas Permukaan Karbon}

Aktif

Adsorpsi senyawa Methylene Blue dilakukan untuk mengukur luas permukaan karbon aktif. Tahap pertama dilakukan pengukuran absorbansi larutan standar Methylene Blue menggunakan UV-VIS yang dapat dilihat pada Tabel 3.1. Persamaan garis lurus hasil regresi linier (Persamaan 3.1) didapatkan dari grafik antara absorbansi (sumbu Y) dan konsentrasi (sumbu X) pada Gambar 3.1.

Tahap kedua yaitu pengukuran absorbansi larutan Methylene Blue dengan yang telah diadsorpsi oleh karbon aktif KA0, KA1, KA2, KA3, dan KA5 menggunakan spektrofotomrter UV-VIS pada panjang gelombang $664 \mathrm{~nm}$. Data absorbansi yang diperoleh kemudian disubstitusi ke Persamaan 3.1 yang hasilnya dapat dilihat pada Tabel 3.2

$$
y=0.1687 x+0.005
$$

Hasil perhitungan pada Tabel 3.2 menunjukkan bahwa daya adsorpsi karbon aktif terhadap Methylene Blue tertinggi terdapat pada variasi konsentrasi aktivator $\mathrm{KOH} 5 \mathrm{M}$. Hal ini dapat dilihat dari konsentrasi Methylene Blue tersisa (tidak teradsorp oleh karbon) paling sedikit yakni 2,152 ppm. Proses aktivasi kimia dan fisika karbon meningkatkan daya adsorpsi karbon meningkat, ditandai dengan konsentrasi Methylene Blue tersisa semakin menurun dari karbon aktif KA0, KA1, KA3, dan KA5. Kemampuan adsorpsi Methylene Blue oleh karbon aktif akan berbanding lurus dengan luas permukaan dari suatu karbon aktif [7]. Luas permukaan dari karbon aktif ditentukan melalui Persamaan 2.1.

Berdasarkan hasil perhitungan sesuai Persamaan 2.1 didapatkan hasil bahwa luas permukaan karbon naik sesuai dengan konsentrasi aktivator $\mathrm{KOH}$ atau berbanding lurus yang dapat dilihat pada Tabel 3.3. Karbon aktif yang memiliki luas permukaan paling besar adalah karbon yang diaktivasi dengan konsentrasi $\mathrm{KOH} 5 \mathrm{M}$ yaitu sebesar $72.413 \mathrm{~m}^{2} / \mathrm{mg}$.

Tabel 3.1 Hasil pengukuran absorbansi larutan standar methylene blue 0-4 ppm.

\begin{tabular}{|l|l|}
\hline Konsentrasi (ppm) & Absorbansi \\
\hline 0 & 0 \\
\hline 1 & 0.194 \\
\hline 2 & 0.349 \\
\hline 3 & 0.457 \\
\hline 4 & 0.712 \\
\hline
\end{tabular}




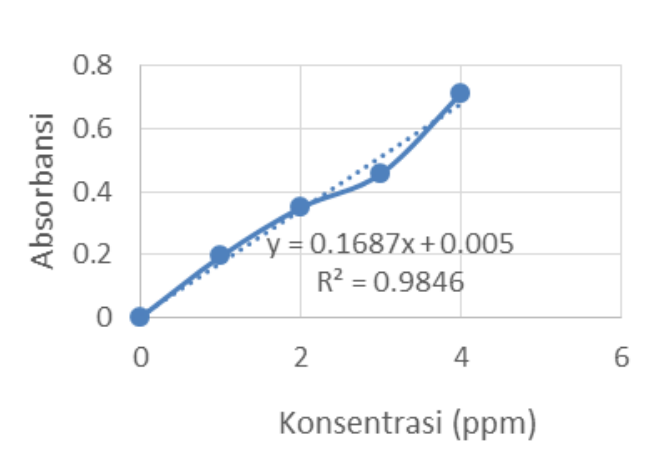

Gambar 3.1 Kurva kalibrasi larutan Methylene Blue 0-4 ppm

Tabel 3.2 Hasil pengukuran absorbansi larutan Methylene Blue setelah diadsorpsi karbon aktif

\begin{tabular}{|c|c|c|}
\hline Kode & Absorbansi & Konsentrasi $(\mathrm{ppm})$ \\
\hline KA0 & 0.872 & 5.139 \\
\hline KA1 & 0.423 & 2.478 \\
\hline KA3 & 0.404 & 2.365 \\
\hline KA5 & 0.368 & 2.152 \\
\hline
\end{tabular}

Tabel 3.3 Luas permukaan karbon dengan variasi aktivator $\mathrm{KOH}$

\begin{tabular}{|c|c|}
\hline Konsentrasi $\mathrm{KOH}[\mathrm{M}]$ & $\mathrm{S}\left(\mathrm{m}^{2} / \mathrm{mg}\right)$ \\
\hline 0 & 70.202 \\
\hline 1 & 72.172 \\
\hline 3 & 72.255 \\
\hline 5 & 72.413 \\
\hline
\end{tabular}

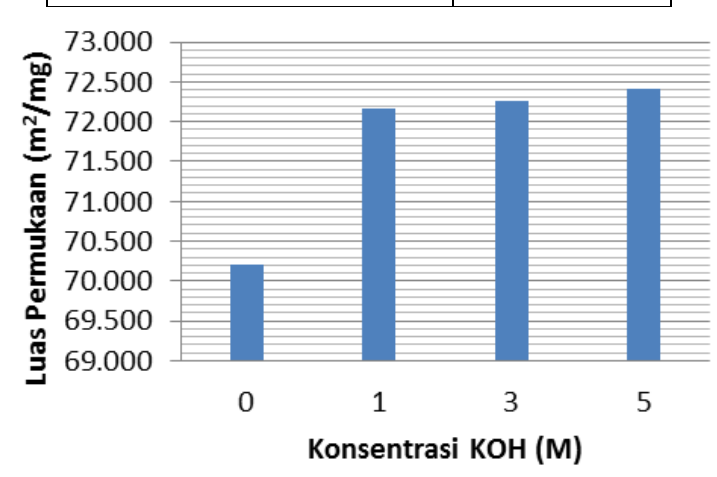

Gambar 3.2 Hubungan antara konsentrasi $\mathrm{KOH}$ terhadap luas permukaan karbon aktif.
Hubungan analisa statistik perbedaan konsentrasi aktivator $\mathrm{KOH}$ terhadap luas permukaan karbon dapat dilihat pada Gambar 3.2. Hasil analisa didapatkan bahwa aktivasi karbon menggunakan $\mathrm{KOH}$ dapat meningkatkan luas permukaan hingga \pm 2000 $\mathrm{m}^{2} / \mathrm{mg}$ karbon. Semakin kecil konsentrasi Methylene Blue yang tersisa dengan meningkatnya luas permukaan karbon aktif memberikan informasi bahwa jumlah Methylene Blue yang teradsorp menjadi lebih banyak. Peningkatan jumlah ini karena pertambahan luas bidang kontak karbon aktif untuk menyerap adsorbat yaitu Methylene Blue. Trend positif dalam adsorpsi ini juga diharapkan akan memberikan hal yang sama untuk proses adsorpsi ion logam $\mathrm{Pb}^{2+}$ dari kawasan perairan Wonorejo Surabaya.

\section{Metode Adsorpsi logam Pb di Kawasan Perairan Wonorejo}

Hasil uji AAS diketahui bahwa kandungan ion logam $\mathrm{Pb}^{2+}$ atau $\mathrm{Pb}$ awal pada sampel air $\mathrm{h}$ dari kawasan Mangrove Wonorejo, Surabaya adalah sebesar 1,8128 ppm. Metode adsorpsi ion logam $\mathrm{Pb}^{2+}$ dalam penelitian ini yaitu dengan karbon aktif berbahan dasar tempurung kelapa. Karbon adalah material berpori yang memiliki permukaan bersifat non polar karena pada permukaannya memiliki unsur karbon bebas yang saling berikatan secara kovalen. Luas permukaan karbon aktif ditentukan oleh 
ukuran pori-porinya. Ukuran pori-pori karbon aktif yang lebih kecil akan menghasilkan luas permukaan yang semakin besar, sehingga kecepatan dan kapasitas dalam proses adsorpsi akan bertambah. Pada penelitian ini peningkatan luas permukaan juga dilakukan dengan aktivasi secara kimia dan fisika agar luas permukaan aktif karbon tempurung kelapa menjadi lebih tinggi. Proses adsorpsi adsorbat pada permukaan karbon aktif mengunakan gaya Van der Waals. Susunan atom pada permukaan karbon aktif mempunyai gaya lebih tidak seimbang daripada susunan atom pada permukaan zat padat secara umum. Oleh karena itu, molekul lain yang berada di sekitar permukaan karbon aktif akan lebih mudah tertarik atau teradsorp ke permukaan karbon aktif mengurangi ketidakseimbangan.

Pada subbab ini akan dibahas hasil adsorpsi ion logam $\mathrm{Pb}^{2+}$ dalam sampel air dari kawasan Mangrove Wonorejo Surabaya menggunakan karbon aktif tempurung kelapa dengan aktivator $\mathrm{KOH}$. Dalam proses adsorpsi ini, pada permukaan karbon aktif atau adsorban akan terbentuk lapisan monolayer ion logam $\mathrm{Pb}^{2+}$ yang mengalami proses difusi menuju pori-pori karbon aktif. Proses ini disebabkan oleh perbedaan konsentrasi ion logam $\mathrm{Pb}^{2+}$ antara permukaan karbon aktif dan yang terlarut dalam sampel air. Ion logam $\mathrm{Pb}^{2+}$ dalam sampel air ditemukan dalam bentuk tersolvasi dengan molekul air $\left(\mathrm{H}_{2} \mathrm{O}\right)$ sehingga akan bersifat polar. Oleh karena permukaan karbon aktif yang bersifat nonpolar dan molekul air $\left(\mathrm{H}_{2} \mathrm{O}\right)$ merupakan molekul polar, maka ion logam $\mathrm{Pb}^{2+}$ pada sampel air yang berada dalam bentuk solvasinya akan dapat diadsorpsi oleh karbon aktif.

Tabel 3.4 Hasil adsorpsi ion logam $\mathrm{Pb}^{2+}$ dalam air waduk mangrove.

\begin{tabular}{|c|c|c|c|c|c|}
\hline \multirow{2}{*}{$\begin{array}{c}{[\mathrm{KOH}]} \\
(\mathrm{M})\end{array}$} & \multirow{2}{*}{$\begin{array}{c}\mathrm{t} \\
(\mathrm{Jam})\end{array}$} & \multicolumn{2}{|c|}{$\begin{array}{c}\text { Konsentrasi } \mathrm{Pb}^{2+} \\
\text { (ppm) }\end{array}$} & \multirow{2}{*}{$\begin{array}{c}\text { Efesiensi } \\
\%\end{array}$} & \multirow{2}{*}{$\begin{array}{c}\text { q } \\
\text { (kapasitas } \\
\text { Adsorpsi) } \\
\text { mg/g }\end{array}$} \\
\hline & & Awal & Akhir & & \\
\hline \multirow[t]{4}{*}{1} & 1 & 1,8128 & 0,3836 & 78,8394 & 0,0286 \\
\hline & 1,5 & 1,8128 & 0,2483 & 86,3030 & 0,0313 \\
\hline & 2 & 1,8128 & 0,7709 & 57,4774 & 0,0208 \\
\hline & 2,5 & 1,8128 & 0,6785 & 62,5717 & 0,0227 \\
\hline \multirow[t]{4}{*}{3} & 1 & 1,8128 & 0,8077 & 57,9876 & 0,0201 \\
\hline & 1,5 & 1,8128 & 0,8723 & 52,9016 & 0,0188 \\
\hline & 2 & 1,8128 & 0,9922 & 53,9166 & 0,0164 \\
\hline & 2,5 & 1,8128 & 1,0199 & 49,8455 & 0,0159 \\
\hline \multirow[t]{4}{*}{5} & 1 & 1,8128 & 1,1121 & 38,6557 & 0,0140 \\
\hline & 1,5 & 1,8128 & 1,2043 & 33,5696 & 0,0122 \\
\hline & 2 & 1,8128 & 1,3149 & 27,4658 & 0,0100 \\
\hline & 2,5 & 1,8128 & 1,3887 & 23,3975 & 0,0085 \\
\hline
\end{tabular}

Pada Tabel 3.4 diketahui bahwa nilai efesiensi dan kapasitas karbon aktif yang paling tinggi adalah nilai pada karbon aktif yang memilki kemampuan paling baik dalam mengadsorp ion logam $\mathrm{Pb}^{2+}$. Pada penelitian ini akan dikaji 2 faktor yang mempengaruhi adsorpsi ion logam $\mathrm{Pb}^{2+}$ pada karbon aktif tempurung kelapa yaitu pengaruh konsentrasi aktivator $\mathrm{KOH}$ dan pengaruh waktu kontak adsorpsi.

Pengaruh penggunaan dan konsentrasi $\mathrm{KOH}$ sebagai aktivator karbon. Secara teori 
aktivator ini akan berperan dalam proses degradasi material yang diaktivasi dengan pembentukan pori-pori sehingga akan meningkatkan luas permukaan. Konsentrasi $\mathrm{KOH}$ dalam sebagai aktivator sangat mempengaruhi daya adsorpsi karbon aktif. Nilai efisiensi adsorpsi karbon aktif terhadapion logam berat akan semakin tinggi dengan bertambahnya konsentrasi aktivator $\mathrm{KOH}$ yang digunakan [8]. Hal ini berhubungan langsung dengan peningkatan jumlah distribusi pori dan luas permukaan karbon aktif sehingga jumlah tempat adsorpsi ion logam bertambah dan demikian juga dengan efesiensinya. Namun, pada Tabel 3.4 diperlihatkan bahwa konsentrasi KOH 1 M untuk semua variasi waktu kontak memberikan nilai efisiensi tertinggi dibandingkan konsentrasi $\mathrm{KOH} 3 \mathrm{M}$ dan 5 M. Pada subbab sebelumnya, pengukuran luas permukaan karbon aktif yang diaktivasi $\mathrm{KOH} 5 \mathrm{M}$ mempunyai luas permukaan yang paling besar yaitu $72.413 \mathrm{~m}^{2} / \mathrm{mg}$, namun pada pengujian adsorpsi ion logam $\mathrm{Pb}^{2+}$ dalam sampel air karbon aktif tersebut tidak memberikan nilai efesiensi yang tinggi. Dalam kasus ini juga terjadi pada karbon aktif yang diaktivasi KOH $3 \mathrm{M}$. Hal ini memberikan hipotesis bahwa adanya kemungkinan teradsorpnya molekul lainnya dengan jumlah yang lebih banyak dibandingkan ion logam $\mathrm{Pb}^{2+}$ pada karbon aktif aktivasi $\mathrm{KOH} 3$ dan $5 \mathrm{M}$, sehingga memberikan efesiensi yang rendah. Sedangkan untuk karbon aktif aktivasi $\mathrm{KOH}$ $1 \mathrm{M}$ lebih banyak menyerap ion logam $\mathrm{Pb}^{2+}$ sehingga lebih selektif. Maka dari itu pada konsentrasi KOH 3 M, Kemampuan adsorpsi ion logam $\mathrm{Pb}^{2+}$ mulai menurun dan berlanjut pada konsentrasi $\mathrm{KOH} 5 \mathrm{M}$, sehingga semakin tinggi konsentrasi semakin menurun kemampuan adsorpsi. Grafik hubungan konsentrasi dan waktu kontak karbon aktif dengan efisiensi adsorpsi ion logam $\mathrm{Pb}^{2+}$ dapat dilihat pada Gambar 3.3.

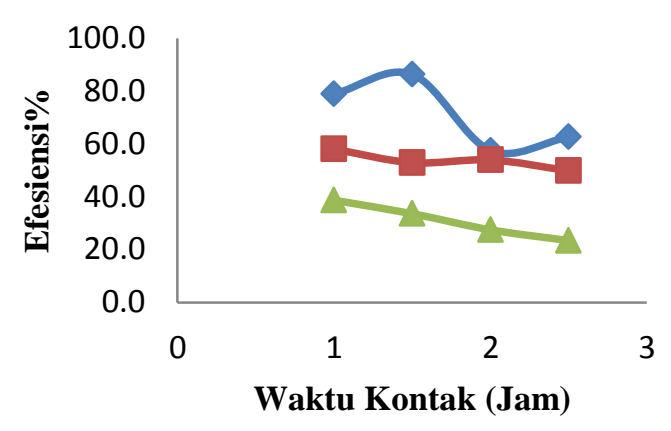

Gambar 3.3 Grafik hubungan konsentrasi $\mathrm{KOH}$ dan waktu kontak 1 jam (४), 1,5 jam (•), 2 jam $(\mathbf{\Delta})$ dan 2,5 jam $(\bullet)$ terhadap efesiensi adsorpsi.

Faktor kedua yang dibahas dalam penelitian ini adalah analisis pengaruh waktu kontak terhadap kemampuan adsorpsi ion logam $\mathrm{Pb}^{2+}$ oleh karbon aktif. Waktu kontak yang digunakan adalah $1 ; 1,5 ; 2$; dan 2,5 jam. Hasil terbaik pada setiap variasi karbon aktif KA1, KA3, dan KA5 diperoleh saat digunakan waktu kontak selama 1 jam untuk KA3 dan KA5, sedangkan KA1 hasil yang terbaik didapatkan pada waktu kontak 1,5 
jam. Hasil ini disebabkan karbon aktif yang diaktivasi $\mathrm{KOH} 1 \mathrm{M}$, membutuhkan waktu lebih lama untuk menyerap ion logam $\mathrm{Pb}^{2+}$ karena mempunyai luas permukaan yang lebih sedikit namun lebih selektif dalam pemilihan molekul adsorpsi yaitu ion logam $\mathrm{Pb}^{2+}$ jika dibandingkan dengan variasi konsentrasi yang lainnya. Pada hasil penelitian diperoleh bahwa efisiensi adsorpsi ion logam $\mathrm{Pb}^{2+}$ oleh karbon aktif akan menurun seiring dengan lamanya waktu kontak atau perendaman (Gambar 3.4). Penurunan ini disebabkan karbon aktif yang akan berada pada titik jenuh yaitu ketika tercapainya keadaan dimana penyerapan ion logam $\mathrm{Pb}^{2+}$ sudah tidak dapat lagi dilakukan oleh karbon aktif.

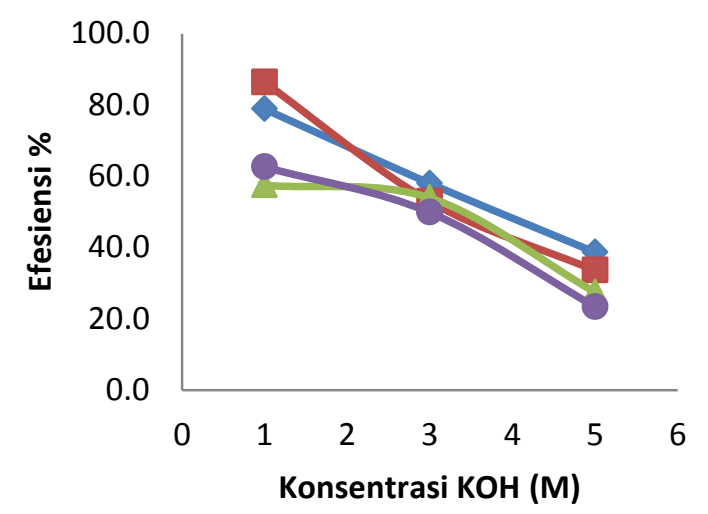

Gambar 3.4 Grafik hubungan waktu kontak dan konsentrasi 1 ppm (४), 3 ppm (•), dan 5 $\operatorname{ppm}(\boldsymbol{\Delta})$ terhadap efesiensi adsorpsi.

\section{Kesimpulan}

Kesimpulan yang dapat diambil dari hasil penelitian ini adalah karbon aktif berbahan dasar tempurung kelapa dapat DOI: http://dx.doi.org/10.12962/j25493736.v4i1.5071 digunakan sebagai adsorben ion logam $\mathrm{Pb}^{2+}$ dalam sampel air kawasan mangrove Wonorejo Surabaya. Hasil adsorpsi terbanyak didapatkan dari karbon aktif yang diaktivasi $\mathrm{KOH} 1 \mathrm{M}$ dengan waktu kontak selama 1,5 jam. Jumlah ion logam $\mathrm{Pb}^{2+}$ yang teradsorp yaitu sebesar $1,5645 \mathrm{ppm}$ atau $86 \%$ dari konsentrasi awal.

\section{Daftar Pustaka}

[1] A. Putra, S. Husrin, "Kualitas Perairan Pasca Cemaran Sampah Laut di Pantai Kuta Bali"Jurnal Ilmu dan Teknologi Kalautan Tropis, vol. 9, Hlm. 57-66, Juni 2017.

[2] R. Azizah, R. Malau, A.B. Susanto, G.W. Santosa, R. Hartati, Irwani dan Suryono, "Kandungan Timbal pada Air, Sedimen, dan Rumput Laut Sargassum sp. Di Perairan Jepara Indonesia"Jurnal Kalautan Tropis, vol. 21(2), Hlm. 155166, November 2018.

[3] H.D. Lindsey, M.M. James, and M.G. Hector. An Assessment of Metal Contamination in Mangrove Sediments and Leaves from Punta Mala Bay, Pacific Panama. MarinePollution Bulletin., Vol 50:, 547-552. 2004.

[4] H. Effendi, . 2003.Telaah Kualitas Air bagi Pengelolaan Sumber Daya dan Lingkungan Perairan. Cetakan Kelima. Yogjakarta : Kanisius.

[5] D. Purwanto, "Arang dari Limbah Tempurung Kelapa Sawit"Jurnal Penelitian Hasil hutan, vol. 29 no. 1, Hlm. 57-66, Maret 2011.

[6] L. Suhendarwati, B. Suharto, dan L.D. Susanawati "Pengaruh Konsentrasi Larutan Kalium Hidroksida pada Abu Dasar Ampas Tebu Teraktivasi”Jurnal 
Sumber Daya Alam \& Lingkungan, vol. 1 no. 1, Hlm. 19-25, Maret 2014.

[7] J. Mustafa \& A.M. Noor. Pembuatan dan Karakterisasi Karbon Aktif dari Ban Bekas dan Penggunaannya untuk Penyerapan Ion-Ion Logam dalam Larutan. Jurnal Kimia Andalas, vol. 9,hlm. 11-15. 2003.

[8] I. A. G. Widihati, G. A. M. D. A. Suastuti, dan M. A. Yohanita Nirmalasari. 2012. Studi Kinetika Adsorpsi Larutan Ion Logam Kromium
(Cr) Menggunakan Arang Batang Pisang (Musa paradisiaca). Skripsi. Jurusan Kimia FMIPA Universitas Udayana. Bukit Jimbaran.

[9] Erlina, Umiatin, dan E. Budi. Pengaruh Konsentrasi Larutan $\mathrm{KOH}$ pada Karbon Aktif Tempurung Kelapa untuk Adsorpsi Logam Cu. Jurnal Fisika Uiversitas Negeri Jakarta. Vol. 4 : 55-60, 2015. 